\title{
Front Matter: Volume 6431
}

, "Front Matter: Volume 6431," Proc. SPIE 6431, Multimodal Biomedical Imaging II, 643101 (22 February 2007); doi: 10.1117/12.727335

SPIE. Event: SPIE BiOS, 2007, San Jose, California, United States 


\section{PROGRESS IN BIOMEDICAL OPTICS AND IMAGING}

Vol. 8, No. 8

\section{Multimodal Biomedical Imaging II}

Fred S. Azar

Editor

20 and 23 January 2007

San Jose, California, USA

Sponsored and Published by

SPIE-The International Society for Optical Engineering 
The papers included in this volume were part of the technical conference cited on the cover and title page. Papers were selected and subject to review by the editors and conference program committee. Some conference presentations may not be available for publication. The papers published in these proceedings reflect the work and thoughts of the authors and are published herein as submitted. The publisher is not responsible for the validity of the information or for any outcomes resulting from reliance thereon.

Please use the following format to cite material from this book:

Author(s), "Title of Paper," in Multimodal Biomedical Imaging II, edited by Fred S. Azar, Proceedings of SPIE Vol. 6431 (SPIE, Bellingham, WA, 2007) Article CID Number.

ISSN 1605-7422

ISBN 9780819465443

Published by

SPIE-The International Society for Optical Engineering

P.O. Box 10, Bellingham, Washington 98227-0010 USA

Telephone 1 360/676-3290 (Pacific Time) · Fax 1 360/647-1445

http://www.spie.org

Copyright @ 2007 , The Society of Photo-Optical Instrumentation Engineers

Copying of material in this book for internal or personal use, or for the internal or personal use of specific clients, beyond the fair use provisions granted by the U.S. Copyright Law is authorized by SPIE subject to payment of copying fees. The Transactional Reporting Service base fee for this volume is $\$ 18.00$ per article (or portion thereof), which should be paid directly to the Copyright Clearance Center (CCC), 222 Rosewood Drive, Danvers, MA 01923. Payment may also be made electronically through CCC Online at http://www.copyright.com. Other copying for republication, resale, advertising or promotion, or any form of systematic or multiple reproduction of any material in this book is prohibited except with permission in writing from the publisher. The CCC fee code is 1605$7422 / 07 / \$ 18.00$.

Printed in the United States of America. 


\title{
Contents
}

\author{
vii Conference Committee \\ ix Introduction
}

\begin{abstract}
SESSION 1 ADVANCES IN SPECTROSCOPIC IMAGING AND MICROSCOPY
643102 Optical scatter imaging: a microscopic modality for the rapid morphological assay of living cells (Invited Paper) [6431-01]

N. N. Boustany, Rutgers Univ. (USA)

643103 Near-infrared optical tomography: endoscopic imaging approach (Invited Paper) [6431-02]

D. Piao, H. Xie, C. Musgrove, C. F. Bunting, W. Zhang, G. Zhang, E. B. Domnick-Davidsion, K. E. Bartels, G. R. Holyoak, Oklahoma State Univ. (USA); S. N. Vemulapalli, Univ. of Oklahoma Health Sciences Ctr. (USA); H. Dehghani, Univ. of Exeter (United Kingdom); B. W. Pogue, Dartmouth College (USA)

643104 Fast optical response to electrical activation in peripheral nerves (Invited Paper) [6431-03] D. K. Chen, Y. Tong, A. Sassaroli, Tufts Univ. (USA); P. R. Bergethon, Boston Univ. Scool of Medicine (USA); S. Fantini, Tufts Univ. (USA)
\end{abstract}

\section{SESSION 2 ANALYSIS AND RECONSTRUCTION TECHNIQUES}

643106 Diffuse optical fluorescence tomography using time-resolved data acquired in transmission [6431-05]

F. Leblond, S. Fortier, ART Advanced Research Technologies, Inc. (Canada); M. P. Friedlander, Univ. of British Columbia (Canada)

643107 Fluorescence optical tomography with a priori information (Invited Paper) [6431-06] M. Guven, B. Yazici, Rensselaer Polytechnic Institute (USA); V. Ntziachristos, Harvard Medical School (USA)

Pagination: Proceedings of SPIE follow an e-First publication model, with papers published first online and then in print and on CD-ROM. Papers are published as they are submitted and meet publication criteria. A unique, consistent, permanent citation identifier (CID) number is assigned to each article at the time of the first publication. Utilization of CIDs allows articles to be fully citable as soon they are published online, and connects the same identifier to all online, print, and electronic versions of the publication.

SPIE uses a six-digit CID article numbering system in which:

- The first four digits correspond to the SPIE volume number.

- The last two digits indicate publication order within the volume using a Base 36 numbering system employing both numerals and letters. These two-number sets start with 00, 01, 02, 03, 04, 05, 06, 07, 08, 09, 0A, OB ... 0Z, followed by 10-1Z, 20-2Z, etc.

The CID number appears on each page of the manuscript. The complete citation is used on the first page, and an abbreviated version on subsequent pages. 
643108 Image reconstruction and evaluation of system performance for optical fluorescence tomography (Invited Paper) [6431-07]

T. Nielsen, B. Brendel, T. Koehler, R. Ziegler, A. Ziegler, Philips Research (Germany);

L. Bakker, M. van Beek, M. van der Mark, M. van der Voort, R. Harbers, Philips Research (Netherlands); K. Licha, M. Pessel, Bayer Schering Pharma AG (Germany); F. Schippers, J. P. Meeuwse, Philips Applied Technologies (Netherlands); A. Feverabend, Philips Design (Netherlands); D. van Pijkeren, S. Deckers, Philips Medical Systems (Netherlands)

643109 Cell segmentation for division rate estimation in computerized video time-lapse microscopy (Invited Paper) [6431-08]

W. He, X. Wang, D. Metaxas, Rutgers Univ. (USA); R. Mathew, E. White, Ctr. for Advanced Biotechnology and Medicine, Rutgers Univ. (USA)

\section{SESSION $3 \quad$ MULTIMODALITY IMAGING}

64310B Structural a priori information in near-infrared optical tomography [6431-10] H. Dehghani, Univ. of Exeter (United Kingdom) and Dartmouth College (USA); C. M. Carpenter, P. K. Yalavarthy, B. W. Pogue, Dartmouth College (USA); J. P. Culver, Washington Univ. in St. Lovis (USA)

64310C Combination of magnetic resonance imaging and diffuse optical spectroscopy to predict radiation response in the breast: an exploratory pilot study (Invited Paper) [6431-11] C. Klifa, J. Hattangadi, M. Watkins, Univ. of California, San Francisco (USA); A. Li, Beckman Laser Institute (USA); T. Sakata, Univ. of California, San Francisco (USA); B. Tromberg, Beckman Laser Institute (USA); N. Hylton, C. Park, Univ. of California, San Francisco (USA)

64310D Simultaneous monitoring of multiple contrast agents using a hybrid MR-DOT system [6431-12]

G. Gulsen, M. B. Unlu, O. Birgul, O. Nalcioglu, Univ. of California, Irvine (USA)

64310F Optical tomography as adjunct to x-ray mammography: methods and results (Invited Paper) [6431-14]

M. Khayat, Z. Ichalalene, N. Mincu, F. Leblond, O. Guilman, S. Djeziri, ART Advanced

Research Technologies, Inc. (Canada)

\section{SESSION 4 NETWORK FOR TRANSLATIONAL RESEARCH IN OPTICAL IMAGING: BREAST CANCER DIFFUSE} OPTICAL IMAGING

$64310 G$ Dynamic frequency domain tomography system and phantom test [6431-15]

S. Jiang, B. W. Pogue, K. D. Paulsen, Dartmouth College (USA)

$64310 \mathrm{H}$ Clinical data analysis for the combined optical and tomosynthesis breast imaging [6431-16]

Q. Fang, J. Selb, S. A. Carp, Massachusetts General Hospital (USA); G. Boverman, Northeastern Univ. (USA); D. B. Kopans, R. H. Moore, Massachusetts General Hospital (USA); D. A. Boas, Massachusetts General Hospital (USA)

64310K A comparison of edge-constrained optical reconstruction methods incorporating spectral and MR-derived spatial information [6431-19]

C. Carpenter, S. Srinivasan, B. Pogue, H. Dehghani, K. D. Paulsen, Dartmouth College (USA) 
$64310 \mathrm{~N}$ Multimodal and multiwavelength imaging in xenografts bearing human tumor cells [6431-22]

S. Kwon, S. Ke, W. Wang, A. G. Cameron, E. M. Sevick Muraca, Baylor College of Medicine (USA)

643100 Fast interactive registration tool for reproducible multispectral imaging for wound healing and treatment evaluation [6431-23]

H. Jan Noordmans, R. de Roode, R. Verdaasdonk, Univ. Medical Ctr. Utrecht (Netherlands)

64310R X-ray and optical multimodality tomographer for small animal examination [6431-26]

A. Da Silva, M. Leabad, T. Bordy, J.-M. Dinten, P. Peltié, P. Rizo, LETI-CEA Minatec (France)

$64310 \mathrm{U}$ Multimodal confocal mosaicing of basal cell carcinomas in Mohs surgical skin excisions [6431-29]

D. S. Gareau, Y. G. Patel, Y. Li, K. S. Nehal, B. Huang, M. Rajadhyaksha, Memorial Sloan Kettering Cancer Ctr. (USA)

64310W Modeling in vivo fluorescence of small animals using TracePro software [6431-31] S. Leavesley, B. Rajwa, Purdue Univ. (USA); E. R. Freniere, L. Smith, R. Hassler, Lambda Research Corp. (USA); J. P. Robinson, Purdue Univ. (USA)

64310Y A new application for displaying and fusing multimodal data sets [6431-33] K. G. Baum, Rochester Institute of Technology (USA) and KGB Technologies (USA); M. Helguera, Rochester Institute of Technology (USA); A. Krol, SUNY Upstate Medical Univ. (USA)

$64310 Z$ Interstitial fluid pressure due to externally applied force in breast tissue [6431-34] A. L. Darling, P. K. Yalavarthy, Dartmouth College (USA); H. Dehghani, Dartmouth College (USA) and Univ. of Exeter (United Kingdom); B. W. Pogue, Dartmouth College (USA)

643110 Using fluorescence molecular tomography for multimodality fusion imaging [6431-35] S. Balasubramanian, B. Carmignani, N. Kujala, D. Pacheco, Univ. of Missouri, Columbia (USA); L. Ma, Univ. of Missouri, Columbia (USA), International Institute of Nano and Molecular Medicine, Univ. of Missouri, Columbia (USA), Radiopharmaceutical Science Institute, Univ. of Missouri, Columbia (USA), and Harry S. Truman Memorial Veterans' Hospital (USA); C. Smith, Univ. of Missouri, Columbia (USA), Radiopharmaceutical Science Institute, Univ. of Missouri, Columbia (USA), and Harry S. Truman Memorial Veterans' Hospital (USA); T. Hoffman, Radiopharmaceutical Science Institute, Univ. of Missouri, Columbia (USA), Univ. of Missouri, Columbia (USA), and Harry S. Truman Memorial Veterans' Hospital (USA); W. Volkert, Univ. of Missouri, Columbia (USA), Radiopharmaceutical Science Institute, Univ. of Missouri, Columbia (USA), and Harry S. Truman Memorial Veterans' Hospital (USA); P. YU, Univ. of Missouri, Columbia (USA)

643112 X-ray guided three-dimensional diffuse optical tomography: in vivo study of osteoarthritis in the finger joints [6431-37]

Q. Zhang, Z. Yuan, Univ. of Florida (USA); E. Sobel, College of Medicine, Univ. of Florida (USA); H. Jiang, Univ. of Florida (USA) 
643113 Design of a frequency domain instrument for simultaneous optical tomography and magnetic resonance imaging of small animals [6431-38]

J. M. Masciotti, S. Rahim, J. Grover, A. H. Hielscher, Columbia Univ. (USA)

Author Index 


\title{
Conference Committee
}

\author{
Symposium Chairs \\ James G. Fujimoto, Massachusetts Institute of Technology (USA) \\ R. Rox Anderson, Wellman Center for Photomedicine (USA), \\ Massachusetts General Hospital (USA) and Harvard School of Medicine \\ (USA)
}

Program Track Chairs

Tuan Vo-Dinh, Duke University (USA)

Anita Mahadevan-Jansen, Vanderbilt University (USA)

Conference Chair

Fred S. Azar, Siemens Corporate Research (USA)

Cochair

Dimitris N. Metaxas, Rutgers University (USA)

Program Committee

Mostafa Analoui, Pfizer Inc. (USA)

Nicholas Ayache, Institut National de Recherche en Informatique et en

Automatique (France)

David A. Boas, Massachusetts General Hospital (USA)

Nada N. Boustany, Rutgers University (USA)

Britton Chance, University of Pennsylvania (USA)

Laurence P. Clarke, National Cancer Institute (USA)

Sergio Fantini, Tufts University (USA)

Keyvan Farahani, National Institutes of Health (USA)

Xavier Intes, Rensselaer Polytechnic Institute (USA)

Mario Khayat, ART Advanced Research Technologies, Inc. (Canada)

Sacha Loiseau, Mauna Kea Technologies (France)

Nassir Navab, Technische Universität München (Germany)

Tim Nielsen, Philips Research Laboratories (Germany)

Vasilis Ntziachristos, Massachusetts General Hospital (USA)

Brian W. Pogue, Dartmouth College (USA)

Susanta K. Sarkar, GlaxoSmithKline (USA)

Yanjun Wu, GlaxoSmithKline (USA)

Birsen Yazici, Rensselaer Polytechnic Institute (USA)

Arjun G. Yodh, University of Pennsylvania (USA)

Yantian Zhang, National Institutes of Health (USA) 


\section{Session Chairs}

1 Advances in Spectroscopic Imaging and Microscopy

Sergio Fantini, Tufts University (USA)

Fred S. Azar, Siemens Corporate Research (USA)

2 Analysis and Reconstruction Techniques

Tim Nielsen, Philips Research Laboratories (Germany)

Fred S. Azar, Siemens Corporate Research (USA)

3 Multimodality Imaging

Catherine S. Klifa, University of California, San Francisco (USA)

Dimitris N. Metaxas, Rutgers University (USA)

$4 \quad$ Network for Translational Research in Optical Imaging: Breast Cancer Diffuse Optical Imaging

Brian W. Pogue, Dartmouth College (USA)

Fred S. Azar, Siemens Corporate Research (USA) 


\section{Introduction}

Data generated by novel imaging technologies such as optical tomography are complex to analyze due to the inherent scattering of light through anatomical systems. Cross-validation and direct comparison with established methods in other imaging modalities are especially challenging. There is critical need for new computational techniques to provide rapid, accurate and cost-effective means for quantification and characterization of such data, either independently or integrated with other modalities. These computational methods will enable faster translation of experimental techniques into viable clinical and/or pre-clinical applications. The applications are diverse and range from imaging at the cellular level to the whole body while incorporating molecular, functional and anatomical information.

The objectives of the Multimodal Biomedical Imaging conference are to provide a forum (1) to review and share recent developments in novel multimodal imaging techniques, (2) highlight development of novel computational methods, and (3) bring together the optical imaging and image analysis communities from other modalities.

Topics include, but are not limited to:

- Multimodal imaging integrating structural and functional information,

- 2D, 3D, 4D, tomographic and/or multi-spectral imaging,

- Imaging and/or image processing techniques applied to optical imaging (e.g. visualization, segmentation, registration),

- Diagnostic analysis techniques which may provide better quantitative and/or diagnostic insight into clinical \& pre-clinical imaging (e.g. methods for quantitative measurements, computer-assisted diagnosis...),

- Imaging and/or image processing techniques used to combine optical imaging with other modalities (e.g. MR, X-Ray, PET...),

- Image analysis, computational methods, and reconstruction approaches which may help bring optical imaging into the clinic.

Fred S. Azar 
Downloaded From: https://www.spiedigitallibrary.org/conference-proceedings-of-spie on 26 Apr 2023

Terms of Use: https://www.spiedigitallibrary.org/terms-of-use 